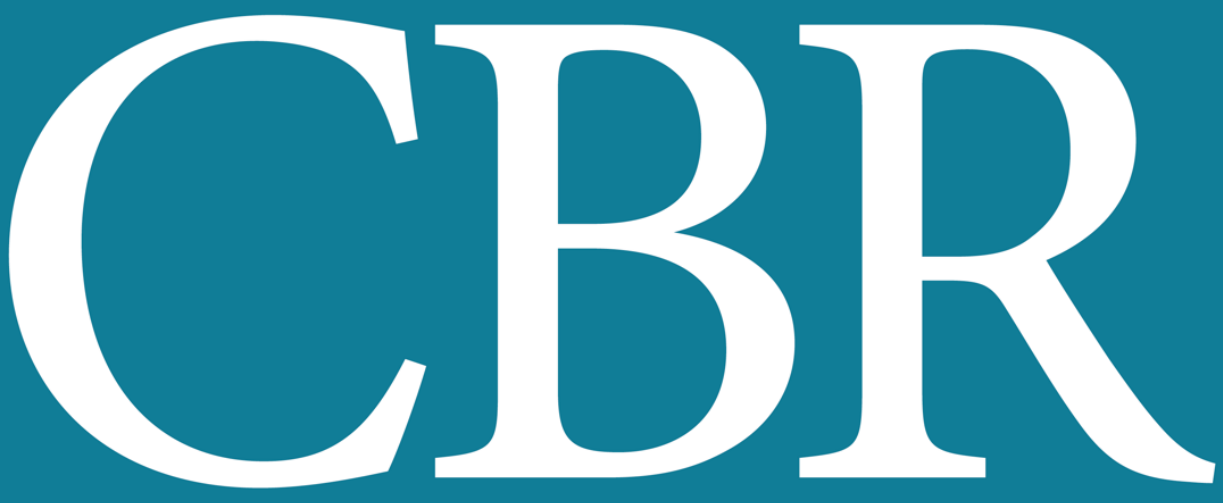

INTERNATIONAL JOURNAL OF CANCER AND BIOMEDICAL RESEARCH

https://jcbr.journals.ekb.eg

Editor-in-chief

Prof. Mohamed Labib Salem, PhD

An Overview on the First Wave of COVID-19 from February to October 2020 in Arab World

Sabry A. El-Naggar, Karim S. El-Said, Wesam S. Meshrif, Ahmed Abdelsadik, Mohamed Ageba, Eman El-Ghohary, Khloud AbuAnber and Mostafa El-Sheekh 


\section{Welcome letter from Editor-in-Chief}

Welcome to the Int J Cancer and Biomedical Research (IJCBR)!

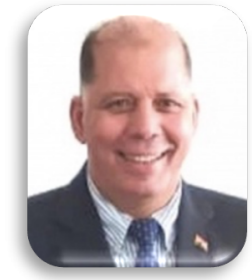

It is with great pleasure that I write this editorial to welcome you to the IJCBR. This journal provides a platform for publication of original and reviews research articles, short communications, letter to editor, thesis abstract, conference report, and case studies. These types of publication are directed at the interface of the fields of cancer and biomedical research.

The IJCBR relies on a distinguished expert of the Advisory and Editorial Board Members from the top international league covering in depth the related topics. They timely review all manuscripts and maintain highest standards of quality and scientific methodology and ethical concepts. Meanwhile, we take all possible means to keep the time of the publication process as short as possible.

I take this chance to welcome your contributions to the IJCBR and have every expectation that it will soon become one of the most respected journals in both the fields of cancer and biomedical research.

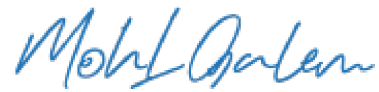

Mohamed L. Salem,

Editor in Chief 


\title{
An Overview on the First Wave of COVID-19 from February to October 2020 in Arab World
}

\author{
Sabry A. El-Naggar ${ }^{1}$, Karim S. El-Said ${ }^{2,3}$, Wesam S. Meshrif ${ }^{1}$, Ahmed Abdelsadik $^{4,5}$, Mohamed Ageba ${ }^{1}$, Eman \\ El-Ghohary, ${ }^{6}$ Khloud Abu-Anber ${ }^{6}$ and Mostafa El-Sheekh ${ }^{6}$ \\ ${ }^{1}$ Zoology Department, Faculty of Science, Tanta University, Tanta, Egypt \\ ${ }^{2}$ National Institute of Material Science, Tsukuba, Ibaraki, Japan \\ ${ }^{3}$ Biochemistry Department, Faculty of Science, Tanta University, Tanta, Egypt \\ ${ }^{4}$ Zoology Department, Faculty of Science, Aswan University, Aswan, Egypt \\ ${ }_{5}^{5}$ Molecular Biotechnology Department, Faculty of Basic Science, El-Galala University, Suez, Egypt \\ ${ }^{6}$ Botany Department, Faculty of Science, Tanta University, Tant, Egypt
}

\section{IIII}

\section{ABSTRACT}

\section{ARTICLE INFO}

The world faces a severe challenge to fight COVID-19 pandemic caused by SARS-CoV2. Millions of calls for medical help were reported due to SARS-CoV-2 infection. Till now, no fixed protocols are known to cure this virus, therefore novel procedures and technologies have been made to avoid infection and death. SARS-CoV- 2 belongs to the coronaviruses, which caused several epidemics in the past. Coronavirus started to invade the world from Wuhan until the present time causing fatal human and economic damages. Given that coronavirus spread in the world in a short time with high severity, the World Health Organization announced that coronavirus is a world pandemic on March 11 $11^{\text {th }}, 2020$. This review article highlights the prevalence and mortality of COVID-19 in the Arab countries during the first wave from February to October 2020. We analyzed the data that were registered monthly in all Arab countries and calculated the indices using correlation analysis. In addition, we discussed the possible routes of infection, clinical symptoms, and biochemical alternation post-SARS-CoV-2 infection, the susceptibility of diabetic patients, immunity against SARS-CoV-2, and new approaches for the treatment of COVID-19. The presented information about COVID-19 in Arab countries can be of help to policymakers, epidemiologists, and medical specialists.

Keywords: Diabetes; insect; outbreak; SARS-CoV-2; treatment.

Editor-in-Chief: Prof. M.L. Salem, PhD - Article DOI: 10.21608/jcbr.2021.64676.1184

\section{Article history}

Received: February 23, 2021

Revised: March 16, 2021

Accepted: March 17, 2021

Correspondence to:

Karim Samy El-Said, PhD

National Institute of Material Science,

Tsukuba, Ibaraki, Japan

Mobile: 080-4119-2223

E-mail: kareem.ali@science.tanta.edu.eg

Sabry A. El-Naggar, PhD

Zoology Department, Faculty of Science,

Tanta University, Tanta, Egypt

Mobile: 01068382357

Email:

sabry.elnaggar@science.tanta.edu.eg

\section{INTRODUCTION}

Coronaviruses are re-emerging viruses that infected millions of people around the world (Shi et al, 2020). On $31^{\text {st }}$ December 2019, the first infected case with SARS-CoV-2 was reported in Wuhan city, Hubei Province, China (Adhikari et al, 2020). SARS-CoV-2 is the causative of COVID-19 (Guo et al, 2020; Qu et al, 2020). It has been reported that it is likely to be a zoonotic disease (Rothan \& Byrareddy, 2020). The virus spread in different cities in China and within a short period, it began to spread to other countries such as Italy, the United States of America, and Germany. Lately, COVID-19 has spread in the entire world (WHO, 2020a). The World Health Organization (WHO) announced that COVID-19 is a world pandemic disease (Peng et al, 2020; Sarzi-Puttini et al, 2020). By $29^{\text {th }}$ January 2020, it permeated the Arab world. The United Arab Emirates was the first Arab country that recorded the transmission of SARSCoV-2. Later, SARS-CoV-2 overspread to other countries such as Lebanon, Iraq, Tunisia, Saudi Arabia, and Egypt, respectively (WHO, 2020a). In April 2020, COVID-19 spread to all Arab world. AS the rate of spread and death due to COVID-19 pandemic in Arab countries is of top priority to the policymakers, epidemiologists and medical specialists, this review aims to describe the prevalence and distribution of COVID-19 during the first wave of SARS-CoV-2 infection from February -October 2020. So that the numbers of infected cases and death 
reported in the Arab world from February to October 2020 were extracted from WHO websites. This information was registered monthly in all Arab countries and the calculated indices were analyzed using correlation analysis. the review also covers other related topics such as symptoms, the possible role of insects in transmission, the entry mechanism of SARS-CoV-2, the relation between COVID-19 infection and diabetes, the beneficial role of natural products for protection, and different approaches of COVID-19 treatment.

\section{Structure of coronavirus}

Coronavirus (SARS-CoV-2) has a poly or spherical shape with a diameter that varies from 150 to $160 \mathrm{~nm}$. Due to its small size, the virus becomes ultra-filterable. Structurally, SARSCoV-2 virus is coated with proteins and a lipid membrane-embedded a single positive-strand RNA. This RNA is about 30,000 nucleotides encodes structural proteins (SP) and nonstructural proteins (NSP). The SPs are four types, including nucleocapsid protein $(\mathrm{N})$, an envelope protein (E), membrane protein (M), and spike protein (S). Coronavirus enveloped a single positive RNA strand randomly (Chen et al, 2007). Nucleocapsid protein interacts with several host-cells and has an antigenic effect. Spike glycoprotein binds to the host receptor that lets the SARS-CoV-2 enter the body cell. This process converts human cells into viral factories to let the virus invade other tissues (Boopathi et al, 2020). SARS-CoV-2 differentiates from other coronaviruses by coding supplemental glycoproteins with acetyl esterase and hemagglutination properties (Kannan et al, 2020).

\section{Entrance mechanism of SARS-CoV-2 into cell}

SARS-CoV-2 has two spike proteins known as S1 and $\mathrm{S} 2$ subunits. The virus enters inside the host cells through the attachment of S1 protein subunit with the cellular angiotensin-converting enzyme 2 (ACE2) receptors that are widely expressed in the respiratory tract, heart (pericytes), kidney, intestine (enterocytes), brain neurons, vascular endothelium, immune cells, renal tubules and pancreatic cells (Wang et al, 2020b). The S2 subunit, containing the fusion peptide and transmembrane domain, led to viral and host cell membrane attachments
(Bergmann \& Silverman, 2020). The S protein subunit promotes viral envelope fusion with the cell membrane of the host cells through the endocytosis pathway. Inside the cell, the virus releases its genomic RNA. This viral RNA is translated into viral replicas polyprotein (pp1a and $1 \mathrm{ab}$ ) then cleaved into small products by viral proteases. The viral protein compartments $(S, M$, and $E)$ and viral genomes were subsequently assembled into viral particles in the endoplasmic reticulum and Golgi apparatus and then transported through vesicles and released out of the cells (Figure 1).

\section{Routes of COVID-19 infection}

Recently, SARS-CoV-2 rabidly spread everywhere due to several factors (Yuen et al, 2020). Transportation ways such as airplanes, ships, and trains between countries and cities led to the fast spread of COVID-19 (Wang et al, 2020a). Infection occurs on direct contact with an infected person through respiratory droplets and saliva that are emitted by breathing, sneezing, and coughing causes infection. Indirect contact with the infected objects, droplets, fomites, focal-oral, blood transfusion. Vertical transmission, an animal to the child, and inhalation droplets of airborne could also cause infection (Asadi et al, 2020; Moghadas et al, 2020; Yu \& Yang, 2020). However, recent studies showed that the increase in temperature and humidity has accompanied by decreasing infection rate and daily death (Tosepu et al, 2020; Xie et al, 2020).

\section{COVID-19 and insects: perspectives}

Person-to-person transmission is thought to occur mainly via respiratory droplets when an infected person coughs or sneezes (Kramer et al, 2006). However, other transmission routes of infection such as stool contamination or by different vectors are possible, but no empirical data are available till now. Previous studies pointed out that SARS-CoV-2 is attacking lymphocytes and shed its particles into the patient's plasma (Grant et al, 2003; Ng et al, 2003). As SARS-CoV-2 appeared in the peripheral circulation of some viraemic patients, they will be available to blood-sucking insects during feeding. Therefore, there is still a theoretical risk of transmission of SARS-CoV-2 through blood transfusion or via blood-sucking 
insects such as mosquitoes and bed-bugs (WHO, $2020 \mathrm{~b})$. The transmission of SARS-CoV-2 by insects has been unexpected by some researchers (Dicke et al, 2020), although some insects such as Aedes sp. as well as ticks are very specific vectors of Arboviruses (Dehghani \& Kassiri, 2020). For the researchers who support the idea that insects cannot transmit SARS-Cov2 infection, several justifications are suggested. Even though, there are few viruses able to infect both humans and insects, however, in general, viruses that infect humans rarely infect insects. The ability of non-blood-feeding insects to humans is restricted and will be only through passive action. Therefore, non-blood-feeding insects contribute no significance to human health (Dicke et al, 2020). However, a scenario that is considered more logical highlighted the probability of transmission of SARS-CoV-2 by insects. Several arguments may support this hypothesis. SARS-CoV-2 is much related to SARS-CoV and Middle East respiratory syndrome (MERS-CoV). These are bat coronaviruses (Kramer et al, 2006). It is very recommended that these viruses are zoonotic, switch into intermediate hosts like civet, pangolin, or camels before they can infect humans (Leitner \& Kumar, 2020). Most bats and pangolin feed on insects (Corman et al, 2014). Moreover, several blood-sucking insects may harbor nidovirales (Nga et al, 2011). Mosquitoes especially Aedes transmit several viruses such as Dengue, Zika, West Nile, Chikungunya, St. Louis encephalitis, Eastern equine encephalitis, and yellow fever viruses (Rosenberg et al, 2018). Recently, Zika and hepatitis C viruses were reported to be transmitted by Culex pipiens (EIKholy et al, 2018; Guo et al, 2016). Given that some blood-sucking insects can take blood contaminated with SARS-CoV-2 from patients, these particles may have one of two ends. If the virus can get into the gut-lining cells, it may be able to replicate or at least drops down from the mouthparts (Calibeo-Hayes et al, 2003). Good support may come from the fact that insects such as Drosophila melanogaster and Anopheles gambiae have ACE analog receptors in gut epithelium, heart cells and the reproductive system (Harrison \& Acharya, 2014; Holt et al, 2002). This receptor is the main point of entry for the virus. It has been demonstrated that the S2 subunit of the spike glycoprotein of Bovine
Coronavirus can mediate membrane fusion in Spodopfera frugperda (Sf9) cells. So that the possibility that insects especially the bloodsucking ones still open (Yoo et al, 1991). There is no confirmed data that insects cannot transmit the virus. Hence, it is much recommended to further examine the ability of blood-sucking insects to keep or transmit SARSCoV-2 to exclude this route.

\section{Clinical symptoms and biochemical alterations of COVID-19}

The influence of COVID-19 revealed a variety of symptoms, ranged from asymptomatic, mild symptoms to severe respiratory failure, and maybe lethal (Esakandari et al, 2020). There is clear evidence that a lot of asymptomatic COVID-19 individuals may spread the virus to other people (Gao et al, 2020). The path of infection gets mild or asymptomatic in about 80 to $90 \%$ of cases. It becomes extreme in about $10 \%$ of cases (Pascarella et al, 2020). The minor symptoms include headache, dizziness, diarrhea, anorexia, nausea and vomiting, and conjunctivitis. Additionally, there are common clinical symptoms of COVID-19 patients that were viral pneumonia, including respiratory distress (dyspnea), high body temperature (fever), severe cough, sore throat, nasal congestion, and myalgia (muscle pain). It is, therefore, hard to distinguish COVID-19 from other respiratory diseases (Li et al, 2020a; Li et al, 2020b). Growing data indicates that coronavirus is not only limited to the respiratory system but also may enter the central nervous system that triggers neurodegenerative disorders (Li et al, 2020a). Besides causing pneumonia, COVID-19 can also damage multiple organs, such as the heart, liver, kidney, as well as multiple systems, such as the blood, immune system, eventually leading to death (Huang et al, 2020; Wang et al, 2020b). After infection with SARS-CoV-2, the patients begin to develop clinical symptoms and signs, for instance, a significant increase in serum proinflammatory cytokine levels, including cytokine storms characterized by IL-6, IL-1 $\beta$, IL2, IL-8, IL-7, CSF, GMCSF, IP10, MCP1, and TNF (Qin et al, 2020; Xu et al, 2020). Due to severe infection with SARS-CoV-2, high levels of proinflammatory cytokines may lead to shock and tissue damage in the heart, liver, and 
kidney, as well as respiratory failure or multiple organ failure (Shi et al, 2020). Infected patients also developed abnormal myocardial enzyme profiles, such as an increase of creatine kinase (CK) and lactate dehydrogenase (LDH). Additionally, infected patients showed an increase in liver enzymes, alanine aminotransferase (ALT), and aspartate aminotransferase (AST). Also, kidney function has been influenced by infection with SARSCoV-2 showing increased blood urea nitrogen and serum creatinine ( $\mathrm{Cr}$ ) (Wang et al, 2020b). Also, age is considered as one of the susceptibility-determining factors in SARS-CoV2 infection. Recent studies showed that the elderly are more susceptible to infection than young people (Garcia et al, 2020; Santesmasses et al, 2020).

\section{Diabetes and COVID-19}

Diabetes is considered one of the most common diseases in the entire world. It consists of 2 types: type 1 diabetes is a metabolic disease that lacks insulin secretion, unlike type 2 diabetes, is the insufficient use of the insulin it produces, and both of them reduce the body's immune response (Angelidi et al, 2020; Yin et al, 2010). Blood glucose regulation has influenced many characteristics of the innate and adaptive immune response. These immunity defects, including insufficient T-cell action, defective natural killer cell activity, complement defects, irregular secretion of adipokines and cytokines such as tumor necrosis factor-alpha (TNF- $\alpha$ ) and interferon due to diabetes, lead to immune defects which in turn facilitate COVID-19 infection (Cai et al, 2020; Gupta et al, 2020). A previous study revealed that there is a positive relationship between type 2 diabetes, obesity, and COVID-19 infection (Johnsson et al, 2015). Also, some studies found that level of D-Dimer and fibrinogen was higher in diabetic patients which may increase the hypercoagulable state caused by COVID-19 inflammations than nondiabetic (Gao et al, 2020).

\section{Immunity to COVID-19}

Immune response to SARS-CoV-2 involves cytokines storm development, toll-like receptors (TLRs), complement activation, augment interferons secretion, increasing monocytes, macrophages, and neutrophils
(Shah et al, 2020; Totura et al, 2015). Activation of ACE2 negatively impacts the physiological process of the body by downregulation of the renin-angiotensin system (RAS) (Corrêa Giron et al, 2020). Association of spike proteins with ACE2 upon the invasion of SARS-COV-2 virus seems to release a considerable amount of cytokine in the body, mainly interleukin-6 (IL-6) that activates the immune response (Conti et al, 2020). Several studies showed that elevation of systemic IL-6 exacerbates SARS-CoV- 2 infection side by side to fibrinogen, D-dimer, and inflammation (Gubernatorova et al, 2020; Hayıroğlu et al, 2020). SARS-CoV-2 infection causes an increase in neutrophil count and decreases lymphocyte. Moreover, it able to induce neutrophil extracellular traps in plasma, tracheal aspirate, and lung tissue that may induce the apoptotic pathways in the lung epithelial cells (Veras et al, 2020). Upon infection with the COVID-19, various proinflammatory cytokines are released from the epithelial cells and fibroblasts that chemoattract massive monocytes to the sites of infection. Then, the activated monocytesmacrophages induced exaggerated cytokine release and, consequently, cytokine release syndrome (CRS) responsible for the acute respiratory distress syndrome (ARDS) typical of severe patients (Gómez-Rial et al, 2020). Tlymphocytes recognize $S$ protein, which correlates with both $\lg G$ and $\lg A$ antibody titers (Braun et al, 2020; Grifoni et al, 2020a). It has been reported that T-cells from patients infected with the SARS-CoV-2 virus recognize only 3 epitopes among 29 shared epitopes of six HLA types. This may suggest that vaccines may confer a short-term immunity against SARSCoV-2 infection, and novel targets needed to be epitomized for natural $\mathrm{CD} 8^{+} \mathrm{T}$ cells (Ferretti et al, 2020).

The development of vaccines against SARS-CoV2 should induce a natural $\mathrm{CD} 8^{+} \mathrm{T}$-cell response, not just confers a short-term immune activation against that virus. Also, considering the variable neutralization activity of patients' serum antibodies (French \& Moodley, 2020; Grifoni et al, 2020b). The appearance of different genetic mutations in the SARS-CoV-2 genome suggests that SARS-CoV-2 virus is unremittingly developing across the whole world (Shah et al, 
2020). Moreover, in most severe cases of SARSCoV-2, significantly decreased count of T cells, helper T-cells, and suppressor T-cells showing lower levels associated with remarkably increased serum levels of pro-inflammatory cytokines such as IL- 6 and TNF- $\alpha$. This indicating loss of effector T-cells and exhaustion of the immune system leading to a poorer immune response and evasion (Chiappelli et al, 2020; Qin et al, 2020). Using TLRs antagonists may become potential therapeutics for SARS-CoV-2 infection. TLR7 is specifically bound to singlestranded RNA viruses such as SARS-CoV-2 and hepatitis $C$ virus, activating the downstream protein MyD88 and subsequently activate NFkB nuclear translocation and mitogen-activated protein kinase (MAPK) pathway (de Marcken et al, 2019; Onofrio et al, 2020). Another potential immunotherapeutic approach is using the cleavage inhibitor to complement system components named Eculizumab (human mAb) that is involved in the assembly of the membrane attack complex (Birra et al, 2020; Cugno et al, 2020).

\section{Confirmed infection and mortality of COVID-19 in the Arab world}

WHO (2020a) reported the confirmed cases and mortalities in different Arab countries starting from February 2020. We generated a regression line for each Arab country from February till October 2020. The highest confirmed cases of coronavirus-infected patients in the Arab world during this period were represented as 127113 , 103052, 94111, 59257, and 43305 in Iraq (September), Saudi Arabia (June), Morocco (October), Jordan (October), and Egypt (June), respectively. In contrast, low numbers of confirmed cases were represented 2 and 3 cases in Mauritania (April) and Somalia (March), respectively (Figure $2 \mathrm{~A}$ ). The high number of mortalities were reported as 2832, 1959, 1473, 1270, and 1007 in Iraq (July), Egypt (June), Morocco (October), Saudi Arabia (July), and Tunisia (October), respectively. Low numbers of mortality were represented in Comoros, Djibouti, Somalia, Mauritania (Figure 2B).

Total cumulative confirmed cases of COVID-19 in the Arab world

The total cumulative COVID-19 infected cases in all Arab world till 31, October 2020 showed that
Iraq, Saudi Arabia, and Morocco reported the highest number of coronavirus-infected cases with 470633, 34688, and 21529, respectively. Qatar, Kuwait, Oman, and Egypt showed moderate confirmed cases with 132343, 125337, 114434, and 107385, respectively. While Syria, Somalia, Yemen, and Comoros represent the lowest infected cases with 5683, 3941,2066 , and 53, respectively. The highest percentage of confirmed cases was found in Iraq that represented $21.85 \%$. While the lowest percentage of confirmed cases was represented $0.02 \%$ in Comoros (WHO, 2020a) (Figure 3).

Total cumulative mortalities of COVID-19 in the Arab world

The total cumulative mortalities due to coronavirus infection in the Arab world from February to October 2020 reported that Iraq, Egypt, Saudi Arabia, and Morocco showed the highest number of mortalities with 10862, 6258,5383 , and 3625, respectively. Lebanon, Yemen, Palestine, and the United Arab Emirates showed moderate mortalities with 625, 600, 553, and 490, respectively. Mauritania, Somalia, Djibouti, and Comoros represented the lowest mortalities with 163, 104, 61, and 7, respectively (WHO, 2020a) (Figure. 4).

\section{Correlation between confirmed cases and mortality}

In the present review, a correlation between the confirmed and mortalities of coronavirus patients in all Arab world till October 2020 was reported (Table 1). Iraq, Saudi Arabia, and Morocco represented the highest countries in confirmed and mortalities. While Comoros, Djibouti, and Somalia showed the lowest countries are confirmed and deaths cases among all Arab world (WHO, 2020a) (Figure 5).

\section{Approaches to COVID-19 treatment}

The antiviral chemical drugs such as Remdesivir, Chloroquine, Tocilizumab, Hydroxychloroquine, Umifenovir, Lopinavir, Oseltamivir, Favipiravir, and many adjunctive curative drugs such as zinc, vitamin $D$, azithromycin, ascorbic acid, nitric oxide, corticosteroids, and IL- 6 antagonists are considered against COVID-19 (Esakandari et al, 2020). 


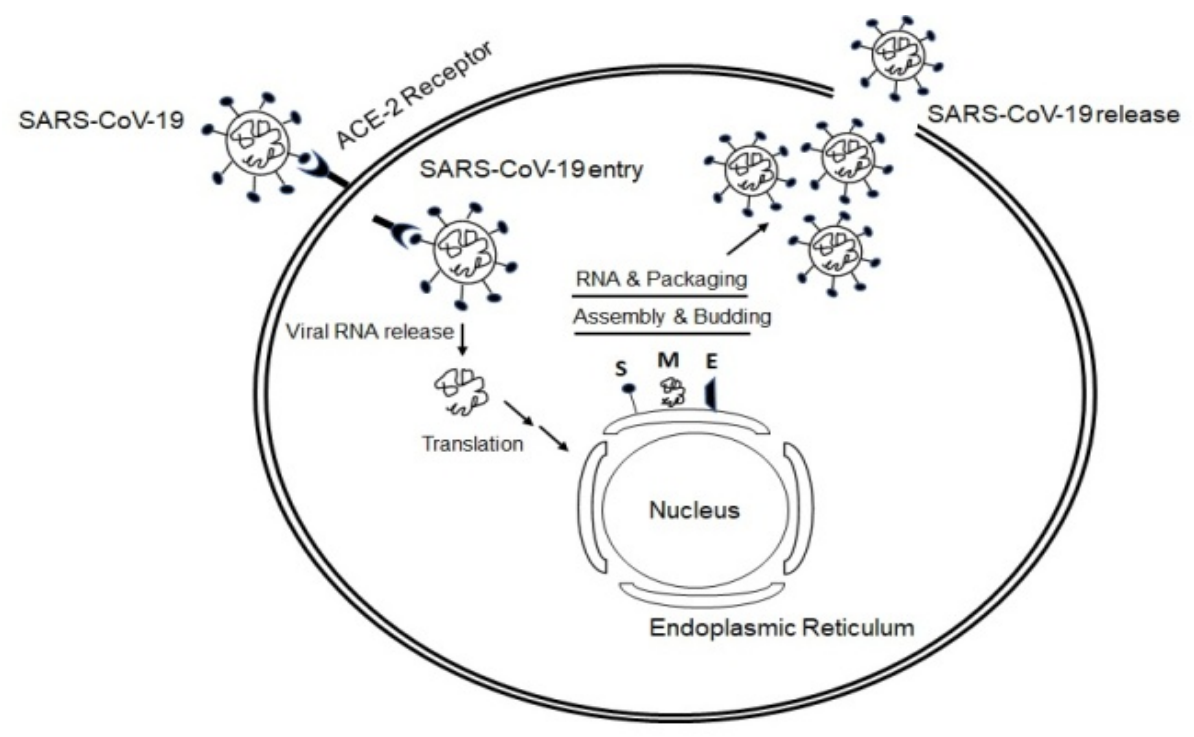

Figure 1. The entrance mechanism of SARS-CoV-2 into the cell.
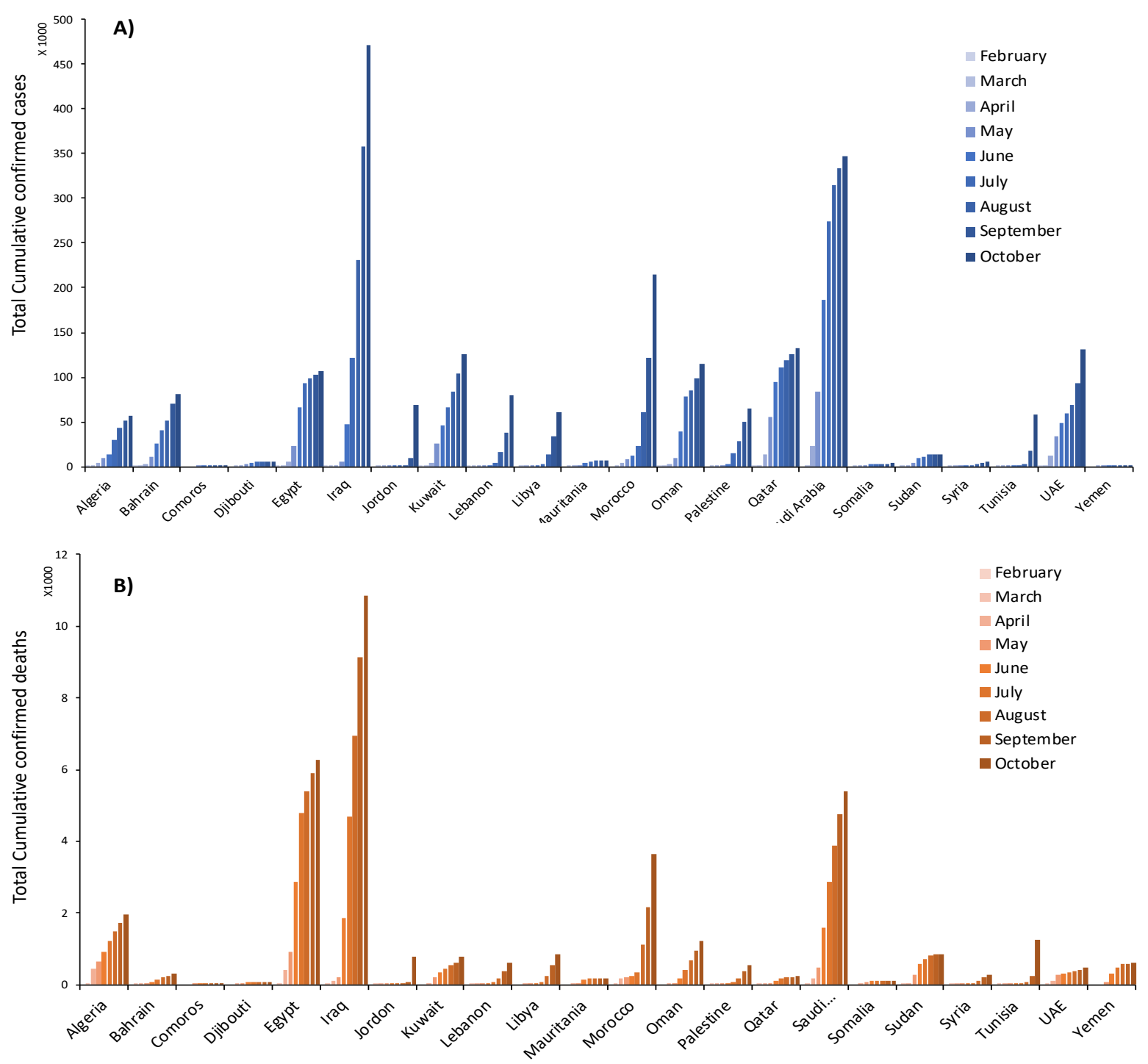

Figure 2. The confirmed cases (A) and death (B) due to COVID-19 in the Arab world from February to October 2020. The numbers of cases and death presented in this figure were obtained from WHO (2020a). 

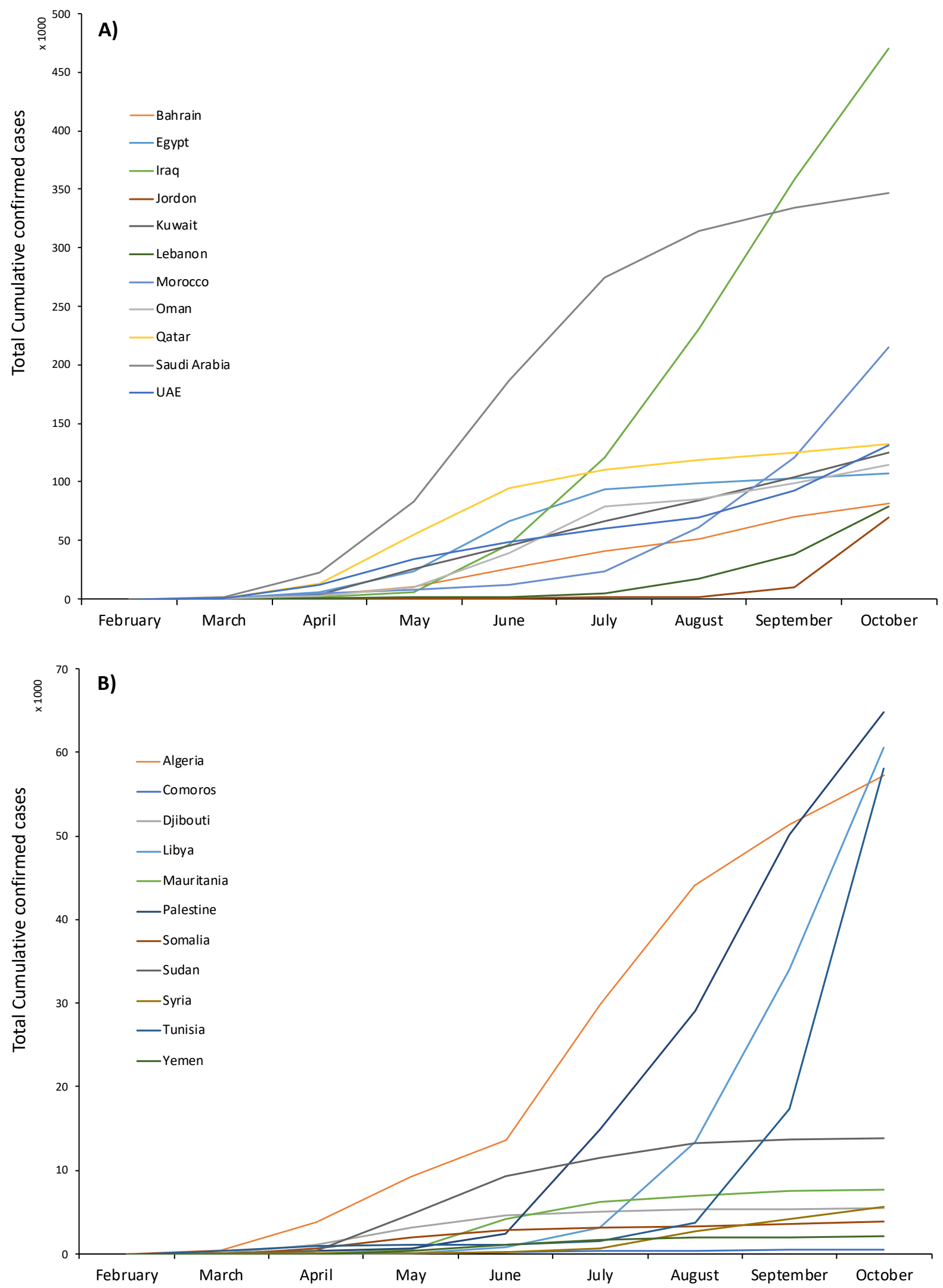

Figure 3. The total cumulative confirmed cases $>65,000$ (A) and $<65,000$ (B) of COVID-19 patients in the Arab countries till $31^{\text {st }}$ October 2020. The numbers of the cumulative cases used in this figure were obtained from WHO (2020a). 

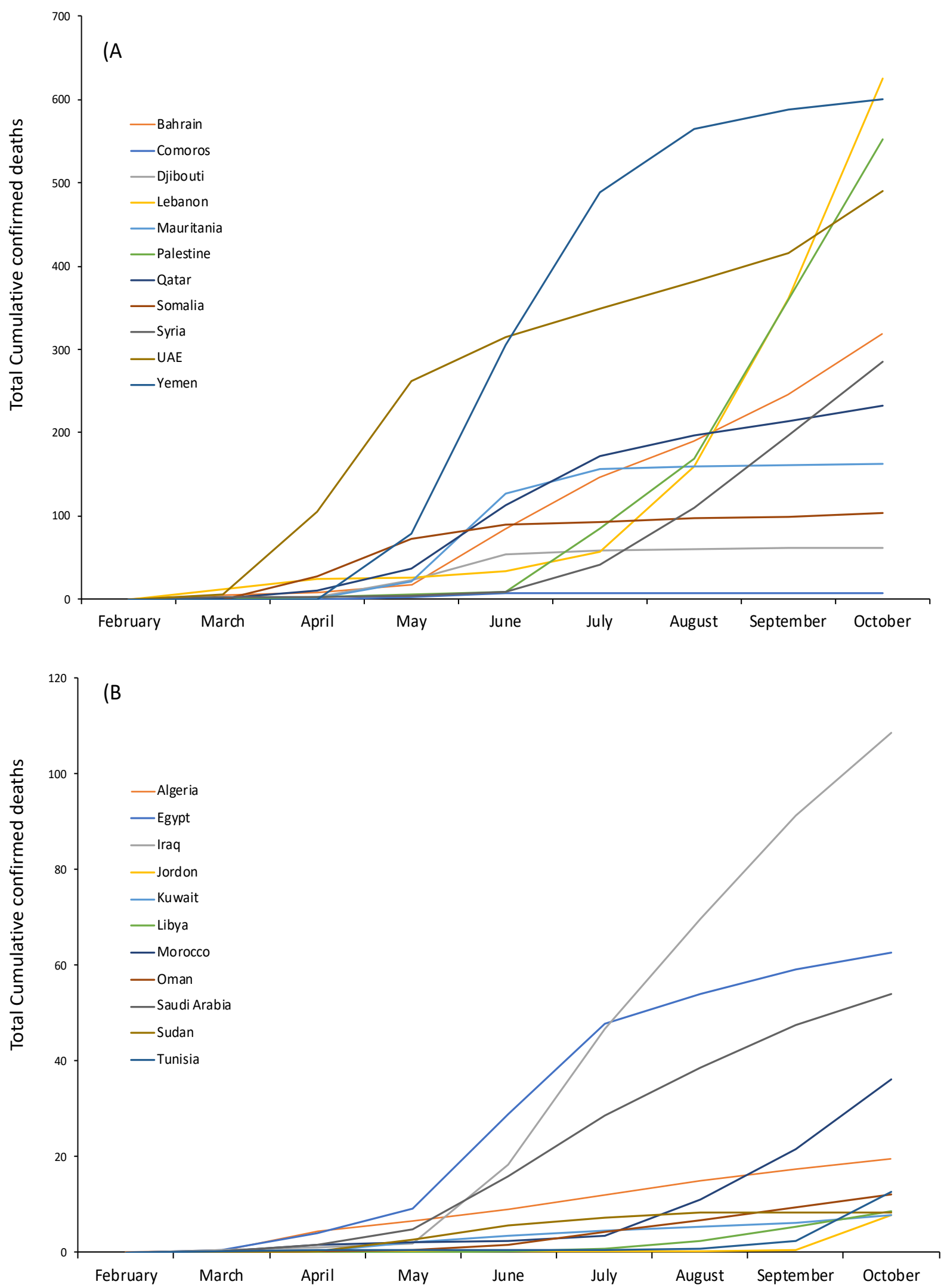

Figure 4. The total cumulative death $>750$ (A) and $<750$ (B)due to COVID-19 in the Arab countries till 31, October 2020. The numbers of the cumulative death used in this figure were obtained from WHO (2020a). 


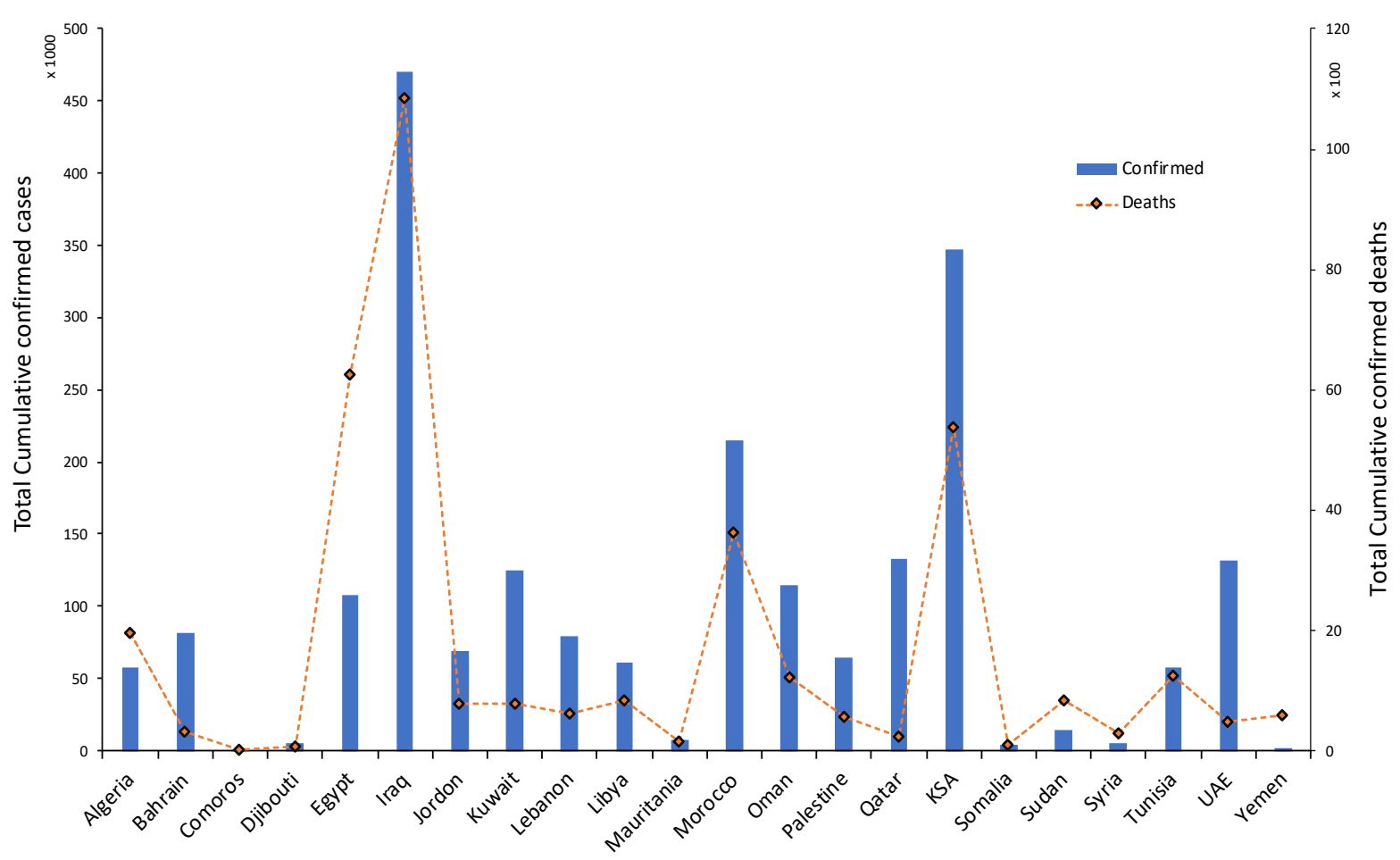

Figure 5. Correlation between the confirmed cases and death in COVID-19 patients in the Arab world till October 2020. The numbers of the cumulative cases and death used in this figure were obtained from WHO (2020a).

Table 1. Pairwise Pearson correlation between total cases, total deaths, total cases, per million, total deaths per million, population, population density, median age, aged 65 older, aged 70 older, GDP per capita, cardiovascular, death rate, Diabetes, prevalence, life expectancy, human development index.

\begin{tabular}{|c|c|c|c|c|c|c|c|c|c|c|c|c|}
\hline & 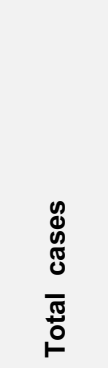 & 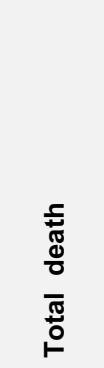 & 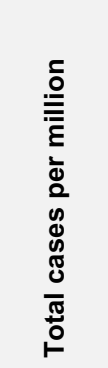 & 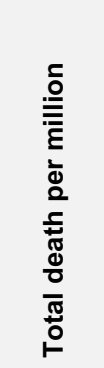 & $\begin{array}{l}\frac{0}{0} \\
\frac{0}{\pi} \\
\frac{\pi}{3} \\
\frac{0}{0}\end{array}$ & $\begin{array}{l}\frac{7}{0} \\
\frac{0}{0} \\
\frac{0}{0} \\
\frac{0}{0} \\
\frac{0}{0}\end{array}$ & 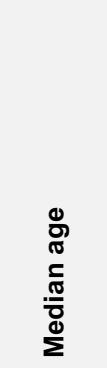 & $\begin{array}{l}\frac{\pi}{ \pm} \\
\frac{0}{0} \\
0 \\
\frac{0}{0} \\
\frac{0}{0}\end{array}$ & 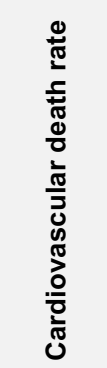 & 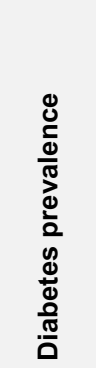 & 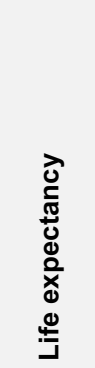 & 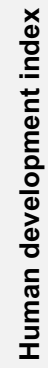 \\
\hline Total cases & 1 & & & & & & & & & & & \\
\hline Total deaths & 0.853 & 1 & & & & & & & & & & \\
\hline Total cases per million & 0.256 & -0.091 & 1 & & & & & & & & & \\
\hline Total death per million & 0.729 & 0.532 & 0.551 & 1 & & & & & & & & \\
\hline Population & 0.274 & 0.648 & -0.366 & -0.055 & 1 & & & & & & & \\
\hline Population density & -0.187 & -0.155 & 0.020 & -0.179 & -0.198 & 1 & & & & & & \\
\hline Median age & 0.227 & -0.071 & 0.597 & 0.426 & -0.183 & 0.196 & 1 & & & & & \\
\hline Aged 65 older & -0.136 & 0.084 & -0.404 & -0.096 & 0.223 & -0.087 & 0.129 & & & & & \\
\hline Aged 70 older & -0.131 & 0.070 & -0.386 & -0.072 & 0.178 & -0.074 & 0.128 & & & & & \\
\hline GDP per capita & 0.318 & -0.069 & 0.786 & 0.280 & -0.224 & 0.103 & 0.676 & 1 & & & & \\
\hline Cardiovascular death rate & -0.300 & 0.084 & -0.651 & -0.514 & 0.643 & -0.385 & -0.393 & -0.440 & 1 & & & \\
\hline Diabetes prevalence & 0.359 & 0.170 & 0.508 & 0.312 & 0.226 & -0.248 & 0.542 & 0.605 & -0.104 & 1 & & \\
\hline Life expectancy & 0.201 & -0.007 & 0.505 & 0.335 & -0.172 & 0.488 & 0.827 & 0.635 & -0.398 & 0.323 & 1 & \\
\hline Human development index & 0.483 & 0.163 & 0.659 & 0.575 & -0.074 & 0.252 & 0.819 & 0.710 & -0.468 & 0.622 & 0.907 & 1 \\
\hline
\end{tabular}

The correlation between variables was calculated based on data registered by Roser et al. (2020). Values in bold red are statistically significant $(P<0.05)$. 
In Egypt, Azithromycin, Ceftriaxone, Ribavirine, Lopinavir/Ritonavir, and Hydroxychloroquine were used to treat COVID-19 (Mostafa et al, 2020).

Natural herbal medicines as curcumin, cinnamon, basil, chili, ginger, turmeric, lemon, fenugreek, neem garlic, onion, black pepper, green tea, and black tea polyphenols have a lot of benefits against symptoms associated with COVID-19 (Mhatre et al, 2020; Thota et al, 2020). Several reports found that red algae (lectin griffithsin and phycocolloid carrageenan), brown algae (fucoidans), green algae (ulvans), and marine algae may have possible antiviral agents against COVID-19 (Pereira \& Critchley, 2020). Convalescent plasma transfusion has been used as an immune therapeutic approach for COVID-19 treatment. These approaches of treatment were applied in some countries around the world such as Egypt, USA, China, Guinea, and Italy (Rajendran et al, 2020). Recently, it was found that the main protease (Mpro) and spike (S) receptor antagonists for SARS-CoV-2 have a significant role during the virus entry into the host cell, which is considered as the primary target for the production of anti-COVID-19 drugs (Sen et al, 2020).

\section{CONCLUSION}

COVID-19 pandemic is a major global health disaster in recent times and considered an unresolved dilemma to the universe. COVID-19 cumulative prevalence differs depending on the country and incidences have been confirmed in almost all continents. The outbreak of the SARSCoV-2 has not only showed the incapability of the worldwide medical system or the public health infrastructure but also caused an economic crisis and social problems that need decades for recovery. Elderly and immunocompromised patients also are susceptible to the virus's mortal impacts. Currently, there is no report for a successful remedy. However, we hope the suggested vaccines could make a difference in the recent future and afford long-time immunity for a human being. Therefore, the virus can be controlled with appropriate prevention strategies. Also, attempts must be made to formulate systematic strategies to prevent such future zoonotic outbreaks. At present, it is imperative to control the wellspring of contamination, reduce the transmission ways, and utilize the current medications and intends to control the advancement of the malady proactively.

\section{CONFLICT OF INTEREST}

All authors have approved this article and declare no conflicts of interest.

\section{FUNDING}

This work did not receive any funds.

\section{References}

Adhikari SP, Meng S, Wu YJ, Mao YP, Ye RX, Wang QZ, Sun C, Sylvia S, Rozelle S, Raat $\mathrm{H}$, Zhou $\mathrm{H}$ (2020). Epidemiology, causes, clinical manifestation and diagnosis, prevention and control of coronavirus disease (COVID-19) during the early outbreak period: a scoping review. Infectious diseases of poverty, 9(1): 112

Angelidi AM, Belanger MJ, Mantzoros CS (2020). Commentary: COVID-19 and diabetes mellitus: What we know, how our patients should be treated now, and what should happen next. Metabolism, 107: 154245

Asadi S, Bouvier N, Wexler AS, Ristenpart WD. (2020). The coronavirus pandemic and aerosols: Does COVID-19 transmit via expiratory particles? Taylor \& Francis.

Bergmann CC, Silverman RH (2020). COVID-19: Coronavirus replication, pathogenesis, and therapeutic strategies. Cleveland Clinic Journal of Medicine, 87:321-327.

Birra D, Benucci M, Landolfi L, Merchionda A, Loi G, Amato P, Licata G, Quartuccio L, Triggiani M, Moscato P (2020). COVID 19: a clue from innate immunity. Immunologic Research, 68: 161-168

Boopathi S, Poma AB, Kolandaivel P (2020). Novel 2019 coronavirus structure, mechanism of action, antiviral drug promises and rule out against its treatment. Journal of Biomolecular Structure and Dynamics, 1-14

Braun J, Loyal L, Frentsch M, Wendisch D, Georg P, Kurth F, Hippenstiel S, Dingeldey M, Kruse B, Fauchere $F$ (2020). SARS-CoV-2-reactive T cells in healthy donors and patients with COVID-19. Nature, 587(7833): 270-274.

Cai S-H, Liao W, Chen S-W, Liu L-L, Liu S-Y, Zheng Z-D (2020). Association between obesity and clinical prognosis in patients infected with 
SARS-CoV-2. Infectious Diseases of Poverty, 9: 1-7

Calibeo-Hayes D, Denning SS, Stringham SM, Guy JS, Smith LG, Watson DW (2003). Mechanical transmission of turkey coronavirus by domestic houseflies (Musca domestica Linnaeaus). Avian Diseases, 47: 149-153

Chen CY, Chang CK, Chang YW, Sue SC, Bai HI, Riang L, Hsiao CD, Huang TH (2007). Structure of the SARS coronavirus nucleocapsid protein RNAbinding dimerization domain suggests a mechanism for helical packaging of viral RNA. Journal of Molecular Biology, 368: 1075-1086

Chiappelli F, Khakshooy A, Greenberg G (2020) CoViD-19 Immunopathology and Immunotherapy. Bioinformation, 16: 219-222

Conti P, Ronconi G, Caraffa A, Gallenga C, Ross R, Frydas I, Kritas S (2020). Induction of proinflammatory cytokines (IL-1 and IL-6) and lung inflammation by Coronavirus-19 (COVI19 or SARS-CoV-2): anti-inflammatory strategies. Journal of Biological Regulators and Homeostatic Agents, 34(2): 327-331

Corman VM, Kallies R, Philipps H, Göpner G, Müller MA, Eckerle I, Brünink S, Drosten C, Drexler JF (2014). Characterization of a novel betacoronavirus related to Middle East respiratory syndrome coronavirus in European hedgehogs. Journal of Virology, 88: 717-724

Corrêa Giron C, Laaksonen A, Barroso da Silva FL (2020). On the interactions of the receptorbinding domain of SARS-CoV-1 and SARS-CoV2 spike proteins with monoclonal antibodies and the receptor ACE2. Virus Research, 285: 198021

Cugno $M$, Meroni PL, Gualtierotti R, Griffini S, Grovetti E, Torri A, Panigada M, Aliberti S, Blasi F, Tedesco F, Peyvandi F (2020). Complement activation in patients with COVID-19: A novel therapeutic target. The Journal of Allergy and Clinical Immunology 146: 215-217

de Marcken M, Dhaliwal K, Danielsen AC, Gautron AS, Dominguez-Villar M (2019). TLR7 and TLR8 activate distinct pathways in monocytes during RNA virus infection. Science Signaling, 12(605):1-18.

Dehghani R, Kassiri H (2020). A Brief Review on the Possible Role of Houseflies and Cockroaches in the Mechanical Transmission of Coronavirus Disease 2019 (COVID-19). Archives of Clinical Infectious Diseases, 15: e102863

Dicke M, Eilenberg J, Salles JF, Jensen A, Lecocq A, Pijlman G, van Loon J, van Oers M (2020). Edible insects unlikely to contribute to transmission of coronavirus SARS-CoV-2. Journal of Insects as Food and Feed, 6(4): 333339.

El-Kholy SE, El-Husseiny IM, Meshrif WS, El-Azm AA, Salem ML (2018). Does the mosquito Culex pipiens represent a potential vector of hepatitis C virus? Medical and Veterinary Entomology, 32: 155-161

Esakandari H, Nabi-Afjadi M, Fakkari-Afjadi J, Farahmandian N, Miresmaeili SM, Bahreini E (2020). A comprehensive review of COVID-19 characteristics. Biological Procedures Online, 22: 1-10.

Ferretti AP, Kula T, Wang Y, Nguyen DM, Weinheimer A, Dunlap GS, Xu Q, Nabilsi N, Perullo $C R$, Cristofaro AW, Whitton $H J$, Virbasius $A$, Olivier KJ, Baiamonte LB, Alistar AT, Whitman ED, Bertino SA, Chattopadhyay S, MacBeath G (2020). COVID-19 Patients Form Memory CD8+ T Cells that Recognize a Small Set of Shared Immunodominant Epitopes in SARSCoV-2. medRxiv: 2020.2007.2024.20161653

French MA, Moodley Y (2020). The role of SARS-CoV2 antibodies in COVID-19: Healing in most, harm at times. Respirology, 25: 680-682

Gao Z, Xu Y, Sun C, Wang X, Guo Y, Qiu S, Ma K (2021). A Systematic Review of Asymptomatic Infections with COVID-19. Journal of Microbiology, Immunology, and Infection, 54(1): 12-16.

Garcia MA, Homan PA, García C, Brown TH (2020). The color of COVID-19: structural racism and the pandemic's disproportionate impact on older racial and ethnic minorities. The Journals of Gerontology: Series B, 76(3): e75e80.

Gómez-Rial J, Rivero-Calle I, Salas A, Martinón-Torres $F$ (2020). Role of monocytes/macrophages in covid-19 pathogenesis: implications for therapy. Infection and Drug Resistance, 13: 2485-2493.

Grant PR, Garson JA, Tedder RS, Chan PKS, Tam JS, Sung JJY (2003). Detection of SARS Coronavirus in Plasma by Real-Time RT-PCR [7]. New England Journal of Medicine, 349: 2468-2469

Grifoni A, Weiskopf D, Ramirez SI, Mateus J, Dan JM, Moderbacher CR, Rawlings SA, Sutherland A, Premkumar L, Jadi RS (2020a). Targets of T cell responses to SARS-CoV-2 coronavirus in humans with COVID-19 disease and unexposed individuals. Cell 181(7): 14891501.

Grifoni A, Weiskopf D, Ramirez SI, Mateus J, Dan JM, Moderbacher CR, Rawlings SA, Sutherland A, Premkumar L, Jadi RS, Marrama $D$, de Silva AM, Frazier A, Carlin AF, Greenbaum JA, 
Peters B, Krammer F, Smith DM, Crotty S, Sette A (2020b). Targets of T Cell Responses to SARS-CoV-2 Coronavirus in Humans with COVID-19 Disease and Unexposed Individuals. Cell, 181: 1489-1501.e1415

Gubernatorova EO, Gorshkova EA, Polinova AI, Drutskaya MS (2020). IL-6: Relevance for immunopathology of SARS-CoV-2. Cytokine Growth Factor Rev, 53: 13-24

Guo W, Li M, Dong Y, Zhou H, Zhang Z, Tian C, Qin R, Wang H, Shen Y, Du K (2020). Diabetes is a risk factor for the progression and prognosis of COVID-19. Diabetes/Metabolism Research and Reviews, e3319

Guo X-x, Li C-x, Deng Y-q, Xing D, Liu Q-m, Wu Q, Sun $A-j$, Dong Y-d, Cao W-c, Qin C-f (2016). Culex pipiens quinquefasciatus: a potential vector to transmit Zika virus. Emerging Microbes \& Infections, 5: 1-5

Gupta R, Hussain A, Misra A (2020). Diabetes and COVID-19: evidence, current status and unanswered research questions. European journal of Clinical Nutrition 74(6): 864-870.

Harrison C, Acharya KR (2014). ACE for all - a molecular perspective. Journal of Cell Communication and Signaling, 8: 195-210

Hayıroğlu M, Ç1nar T, Tekkeşin Ai (2020). Fibrinogen and D-dimer variances and anticoagulation recommendations in Covid-19: current literature review. Revista da Associação Médica Brasileira, 66: 842-848

Holt RA, Subramanian GM, Halpern A, Sutton GG, Charlab R, Nusskern DR, Wincker P, Clark AG, Ribeiro JC, Wides R (2002). The genome sequence of the malaria mosquito Anopheles gambiae. Science, 298: 129-149

Huang C, Wang Y, Li X, Ren L, Zhao J, Hu Y, Zhang L, Fan G, Xu J, Gu X, Cheng Z, Yu T, Xia J, Wei Y, Wu W, Xie X, Yin W, Li H, Liu M, Xiao Y, Gao H, Guo L, Xie J, Wang G, Jiang R, Gao Z, Jin Q, Wang J, Cao B (2020). Clinical features of patients infected with 2019 novel coronavirus in Wuhan, China. Lancet, 395: 497-506

Johnsson IW, Haglund B, Ahlsson F, Gustafsson J (2015). A high birth weight is associated with increased risk of type 2 diabetes and obesity. Pediatric Obesity, 10: 77-83

Kannan S, Shaik Syed Ali P, Sheeza A, Hemalatha K (2020). COVID-19 (Novel Coronavirus 2019) recent trends. European Review for Medical and Pharmacological Sciences, 24: 2006-2011

Kramer U, Kipervasser S, Neufeld MY, Fried I, Nagar $S$, Andelman $F$ (2006). Is there any correlation between severity of epilepsy and cognitive abilities in patients with temporal lobe epilepsy? European Journal of Neurology, 13: 130-134
Leitner T, Kumar S (2020). Where Did SARS-CoV-2 Come From? Molecular Biology and Evolution 37: 2463-2464

Li Lq, Huang T, Wang Yq, Wang Zp, Liang Y, Huang Tb, Zhang Hy, Sun W, Wang Y (2020a) COVID-19 patients' clinical characteristics, discharge rate, and fatality rate of meta-analysis. Journal of Medical Virology, 92: 577-583

Li YC, Bai WZ, Hashikawa T (2020b). The neuroinvasive potential of SARS-CoV2 may play a role in the respiratory failure of COVID19 patients. Journal of Medical Virology, 92: 552-555

Mhatre S, Srivastava T, Naik S, Patravale V (2020). Antiviral activity of green tea and black tea polyphenols in prophylaxis and treatment of COVID-19: A review. Phytomedicine: International Journal of Phytotherapy and Phytopharmacology, 153286

Moghadas SM, Fitzpatrick MC, Sah P, Pandey A, Shoukat A, Singer BH, Galvani AP (2020). The implications of silent transmission for the control of COVID-19 outbreaks. Proceedings of the National Academy of Sciences of the United States of America, 117: 17513-17515

Mostafa AS, Abdalbaky A, Fouda E, Shaaban HH, Elnady HG, Hassab-Allah M, Rashad MM, El Attar MM, Alfishawy M, Hussien SM (2020) Practical approach to COVID-19: an Egyptian pediatric consensus. Egyptian Pediatric Association Gazette, 68: 1-8

Ng EKO, Hui DS, Chan KCA, Hung ECW, Chiu RWK, Lee N, Wu A, Chim SSC, Tong YK, Sung JJY, Tam JS, Lo YMD (2003). Quantitative Analysis and Prognostic Implication of SARS Coronavirus RNA in the Plasma and Serum of Patients with Severe Acute Respiratory Syndrome. Clinical Chemistry, 49: 1976-1980

Nga PT, Parquet MdC, Lauber C, Parida M, Nabeshima T, Yu F, Thuy NT, Inoue $S$, Ito $T$, Okamoto K, Ichinose A, Snijder EJ, Morita K, Gorbalenya AE (2011). Discovery of the First Insect Nidovirus, a Missing Evolutionary Link in the Emergence of the Largest RNA Virus Genomes. PLOS Pathogens, 7: e1002215

Onofrio L, Caraglia M, Facchini G, Margherita V, Placido S, Buonerba C (2020). Toll-like receptors and COVID-19: a two-faced story with an exciting ending. Future Science $O A, 6$ : FSO605

Pascarella G, Strumia A, Piliego C, Bruno F, Del Buono R, Costa F, Scarlata S, Agro FE (2020). COVID19 diagnosis and management: a comprehensive review. Journal of Internal Medicine, 288: 192-206

Peng F, Tu L, Yang Y, Hu P, Wang R, Hu Q, Cao F, Jiang T, Sun J, Xu G, Chang C (2020). Management 
and Treatment of COVID-19: The Chinese Experience. The Canadian Journal of Cardiology, 36: 915-930

Pereira L, Critchley AT (2020). The COVID 19 novel coronavirus pandemic 2020: seaweeds to the rescue? Why does substantial, supporting research about the antiviral properties of seaweed polysaccharides seem to go unrecognized by the pharmaceutical community in these desperate times? Journal of Applied Phycology, 2: 1875-1877.

Qin C, Zhou L, Hu Z, Zhang S, Yang S, Tao Y, Xie C, Ma K, Shang K, Wang W, Tian DS (2020). Dysregulation of Immune Response in Patients With Coronavirus 2019 (COVID-19) in Wuhan, China. Clinical infectious diseases: an official publication of the Infectious Diseases Society of America, 71: 762-768

Qu G, Li X, Hu L, Jiang G. (2020). An imperative need for research on the role of environmental factors in transmission of novel coronavirus (COVID-19). ACS Publications.

Rajendran K, Krishnasamy N, Rangarajan J, Rathinam J, Natarajan M, Ramachandran A (2020). Convalescent plasma transfusion for the treatment of COVID-19: Systematic review. Journal of Medical Virology, 92: 1475-1483

Rosenberg R, Lindsey NP, Fischer M, Gregory CJ, Hinckley AF, Mead PS, Paz-Bailey G, Waterman SH, Drexler NA, Kersh GJ (2018). Vital signs: trends in reported vectorborne disease cases-United States and Territories, 2004-2016. Morbidity and Mortality Weekly Report, 67(17): 496.

Roser M, Ritchie H, Ortiz-Ospina E, Hasell J, (2020). Coronavirus Pandemic (COVID-19). Published online at OurWorldInData.org.

Rothan HA, Byrareddy SN (2020). The epidemiology and pathogenesis of coronavirus disease (COVID-19) outbreak. Journal of Autoimmunity, 109: 102433

Santesmasses D, Castro JP, Zenin AA, Shindyapina AV, Gerashchenko MV, Zhang B, Kerepesi C, Yim SH, Fedichev PO, Gladyshev VN (2020). COVID-19 is an emergent disease of aging. Aging Cell, 19(10): e13230.

Sarzi-Puttini P, Giorgi V, Sirotti S, Marotto D, Ardizzone S, Rizzardini G, Antinori S, Galli M (2020). COVID-19, cytokines and immunosuppression: what can we learn from severe acute respiratory syndrome? Clinical and Experimental Rheumatology, 38: 337-342

Sen D, Debnath P, Debnath B, Bhaumik S, Debnath S (2020). Identification of potential inhibitors of SARS-CoV-2 main protease and spike receptor from 10 important spices through structurebased virtual screening and molecular dynamic study. Journal of Biomolecular Structure and Dynamics, 1-22

Shah VK, Firmal P, Alam A, Ganguly D, Chattopadhyay S (2020). Overview of Immune Response During SARS-CoV-2 Infection: Lessons From the Past. Frontiers in Immunology, 11

Shi Y, Wang G, Cai XP, Deng JW, Zheng L, Zhu HH, Zheng M, Yang B, Chen Z (2020). An overview of COVID-19. Journal of Zhejiang University Science $B, 21:$ 343-360

Thota SM, Balan V, Sivaramakrishnan V (2020). Natural products as home-based prophylactic and symptom management agents in the setting of COVID-19. Phytotherapy Research, 34(12): 3148-3167.

Tosepu R, Gunawan J, Effendy DS, Lestari H, Bahar H, Asfian P (2020). Correlation between weather and Covid-19 pandemic in Jakarta, Indonesia. Science of The Total Environment, 725: 138436.

Totura AL, Whitmore A, Agnihothram S, Schäfer A, Katze MG, Heise MT, Baric RS (2015). Toll-Like Receptor 3 Signaling via TRIF Contributes to a Protective Innate Immune Response to Severe Acute Respiratory Syndrome Coronavirus Infection. mBio, 6: e00638-00615

Veras FP, Pontelli M, Silva C, Toller-Kawahisa J, de Lima M, Nascimento D, Schneider A, Caetite D, Rosales R, Colon D, Martins R, Castro I, Almeida G, Lopes MI, Benatti M, Bonjorno L, Giannini M, Luppino-Assad R, Almeida S, Vilar F, Santana R, Bollela V, Martins M, Miranda C, Borges M, Pazin-Filho A, Cunha L, Zamboni D, Dal-Pizzol F, Leiria L, Siyuan L, Batah S, Fabro A, Mauad T, Dolhnikoff M, Duarte-Neto A, Saldiva P, Cunha T, Alves-Filho JC, Arruda E, Louzada-Junior P, Oliveira R, Cunha F (2020). SARS-CoV-2 triggered neutrophil extracellular traps (NETs) mediate COVID-19 pathology. medRxiv: 2020.2006.2008.20125823

Wang D, Hu B, Hu C, Zhu F, Liu X, Zhang J, Wang B, Xiang $\mathrm{H}$, Cheng Z, Xiong Y, Zhao Y, Li Y, Wang $X$, Peng Z (2020a). Clinical Characteristics of 138 Hospitalized Patients With 2019 Novel Coronavirus-Infected Pneumonia in Wuhan, China. JAMA, 323: 1061-1069

Wang T, Du Z, Zhu F, Cao Z, An Y, Gao Y, Jiang B (2020b). Comorbidities and multi-organ injuries in the treatment of COVID-19. Lancet, 395: e52

WHO. (2020a). Infection Prevention and Control (IPC) for COVID-19 Virus. World Health Organization, Geneva.

WHO. (2020b). Vector-borne diseases. World Health Organization Geneva. 
Xie C, Jiang L, Huang $G, P u H$, Gong $B$, Lin $H$, Ma $S$, Chen $X$, Long $B$, Si G, Yu H, Jiang L, Yang X, Shi $Y$, Yang $Z$ (2020). Comparison of different samples for 2019 novel coronavirus detection by nucleic acid amplification tests. International Journal of Infectious Diseases, 93: 264-267

Xu P, Xing X, Yu K, Lv Z, Cui H, Shi Y, Chang T, Zhang D, Zhang Y, Wang K, Lu J, Huang Q, Li X, Cui Y, Shi L, Wang T, Niu J, Wang J (2020). Profiles of COVID-19 clinical trials in the Chinese Clinical Trial Registry. Emerging Microbes \& Infections, 9: 1695-1701

Yin B, Ma G, Yen CY, Zhou Z, Wang GX, Divino CM, Casares S, Chen SH, Yang WC, Pan PY (2010).
Myeloid-derived suppressor cells prevent type 1 diabetes in murine models. Journal of Immunology, 185: 5828-5834

Yoo D, Parker MD, Babiuk LA (1991). The S2 subunit of the spike glycoprotein of bovine coronavirus mediates membrane fusion in insect cells. Virology, 180: 395-399

Yu X, Yang R (2020). COVID-19 transmission through asymptomatic carriers is a challenge to containment. Influenza and Other Respiratory Viruses, 14(4): 474-475.

Yuen K-S, Ye Z-W, Fung S-Y, Chan C-P, Jin D-Y (2020). SARS-CoV-2 and COVID-19: The most important research questions. Cell \& Bioscience, 10: 1-5. 


\section{Egyptian Association for Cancer Research (EACR)}

http://eacr.tanta.edu.eg/

EACR is an NGO society that was declared by the Ministry of Social Solidarity (Egypt) No. 1938 in 19/11/2014 based on the initiative of Prof. Mohamed Labib Salem, the current Chairman of EACR. EACR aims primarily to assist researchers, in particular young researchers in the field of cancer research through workshops, seminars and conferences. Its first international annual conference entitled "Anti-Cancer Drug Discovery" was successfully organized in April 2019 (http://acdd.tanta.edu.eg). Additionally, EACR aims to raise the awareness of the society about the importance of scientific research in the field of cancer research in prediction, early diagnosis and treatment of cancer. EACR is also keen to outreach the scientific community with periodicals and news on cancer research including peer-reviewed scientific journals for the publication of cutting-edge research. The official scientific journal of EACR is "International Journal of Cancer and biomedical Research (IJCBR: https://jcbr.journals.ekb.eg) was successfully issued in 2017 and has been sponsored by the Egyptian Knowledge Bank (EKB: www.ekb.eg).

\section{EACR Chairman,}

Prof. Mohamed Labib Salem, PhD

Professor of Immunology

Faculty of Science, Tanta Universiy, Egypt 
International Journal of Cancer and Biomedical Research (IJCBR), a publication of the Egyptian Association for Cancer Research (EACR), is a peer-reviewed online journal published quarterly. The journal allows free access (Open Access) to its contents and permits authors to self-archive a final accepted version of the articles on any OAl-compliant institutional / subject-based repository.

\section{Aim And Scope}

Aim: The main aim of IJCBR is to attract the best research in animal and human biology in health and diseases from across the spectrum of the biomedical sciences at the molecular, cellular, organ, and whole animal levels especially those that are related to cancer research, including causes, prediction, diagnosis, prognosis and therapy.

Scope: It is essential reading for all researchers interested in biochemistry, cancer, microbiology, nutrition, physiology, genetics, immunology, epidemiology, medical economics, human biology, bioinformatics, biotechnology, nanotechnology, and disease modeling.

\section{Publication Ethics}

Researchers should conduct their research from research proposal to publication in line with the best practices and codes of conduct of relevant professional bodies and/or national and international regulatory bodies. IJCBR accepts manuscripts prepared in accordance with the "Uniform Requirements for Submission of Manuscripts for Biomedical Journals adopted by the International Committee of Medical Journal Editors (ICMJE) and the Committee on Publication Ethics (COPE). Details of ICMJE and COPE are available at http://www.icmje.org/ and http://publicationethics.org/

\section{Peer Review Process}

After the IJCBR editor receives a manuscript, the first step is to confirm that the manuscript meets the journal's rules for content and format, including similarity check (plagiarism) which should be less than $25 \%$. If the manuscript meets the journal's rules, the editor then assign it to the double-blind peer review process. The IJCBR editor send the manuscript to at least two experts in the field for RIGOROUS scientific evaluation. The experts called peer reviewers - will then prepare a report that assesses the manuscript and return it to the editor through the IJCBR portal. Upon the first submission, this reviewing process takes about 4 to 6 weeks. After reading the peer reviewer's report, the editor will decide one of the following four options:

1. Reject the manuscript.

2. Accept the manuscript

3. Ask the authors to revise and resubmit the manuscript after responding to the peer reviewers' feedback.

4. Ask for peer-review from additional reviewers.

If the authors resubmit the manuscript, the IJCBR editor will ask the same peer-reviewers to look over the manuscript again to confirm that their concerns have been addressed. This is called re-review process. This second revision (if applicable) takes about another 4 to 6 weeks. At this point, the abstract of the article appears in press. The online publication (the PDF format) of the final version of the manuscript takes from 2 to 4 weeks. As such, the total publication cycle takes from 2 to 4 months. This cycle can be reduced to 4 to 6 weeks (fast track publication) for the manuscripts with outstanding findings.

The peer-review process used by IJCBR includes comments on errors in the study's methods or analysis that raise questions about the findings, or sections that need clearer explanations. The peer-review process also includes the importance and novelty of the manuscript and its interest to the journal's audience. The IJCBR uses double-blind review, which means that both the reviewers and authors identities are concealed from the reviewers, and vice versa, throughout the review process. To facilitate this, authors need to submit a Title Page containing the Authors details and Blinded Manuscript with no author details as 2 separate files. 


\section{Publisher}

The International Journal of Cancer and Biomedical Research (IJCBR) is an International and interdisciplinary journal of preclinical and clinical studies in the area of cancer and biomedical research. It is a peer-reviewed journal in English, published quarterly (in March, June, September, and December) by the Egyptian Association for Cancer Research (EACR) in both print and online formats (4 issues making a volume). Special issues or supplements may also be produced from time to time upon agreement with the Editorial Board.

\section{Scope}

The main aim of IJCBR is to attract the best research in animal and human biology in health and diseases from across the spectrum of the biomedical sciences at the molecular, cellular, organ, and whole animal levels especially those that are related to cancer research, including causes, prediction, diagnosis, prognosis and therapy.

\section{Publication Fees}

The journal does charge for submission, processing or publication of manuscripts (2000 LE for Egyptians or $\$ 300$ for non-Egyptians; EACR members receive 15\% discount on publication). Of them Peer-review fees (300 LE) should be paid on submission (non-refundable). For the fast track production of the accepted manuscript, another $500 \mathrm{LE}$ is paid.

General specifications for different types of article

- Submitted manuscripts should not have been published previously, except in a limited form (e.g. short communication to a symposium or as part of MSc or PhD theses) and should not be under consideration for publication by other journals.

- All co-authors should agree with the content of the manuscript. Authors must have obtained permission to use any copyrighted material in the manuscript before submission.

\section{IJCBR publishes different types of articles}

- Original Article (6000 words with $\mathbf{4}$ tables and $\mathbf{4}$ figures, maximum $\mathbf{8}$ display items): Articles with novel findings are the target of IJCBR. Articles presenting a detailed description of a new technique, comparison of existing methods, meta-analyses with comprehensive and in-depth discussion are considered. Papers in a numbered series are not accepted unless all are submitted at the same time.

- Short communications or case study (3000 words with 4 display items): Short communications present exceptionally exciting, novel or timely contents are considered. They will be peer-reviewed in the same way as research papers. The references are restricted to 15 .

- Reviews or systematic review (9000 words with $\mathbf{1 0}$ display items): They are invited by the Editorial Board or unsolicited. Review articles have to be contemporary and comprehensive and add information to the knowledge. Sharp critical analyses of novel data or concepts are encouraged. When relevant, a statistical analysis of data and a meta-analysis approach are recommended.

- Opinion papers, letter to the editor or comment to the editor (1500 words with $\mathbf{2}$ display items): They are submitted by invitation of the Editorial Board. They are short papers, which aim to inform scientists, industry, and the public and policymakers about cutting-edge issues in research or the impact of research. They reflect the opinion of their authors who bear full responsibility of the published paper. The references are restricted to 10 .

- Conference/Symposium papers: The journal will consider for publication the results of original work and critical reviews that are presented at conferences/symposia. Symposium organizers who wish to publish bundles of papers from a symposium/conference in IJCBR should first contact the Editor-inChief of the IJCBR (EACR@unv.tanta.edu.eg) for agreement. Supplementary material can be proposed and will be made available online. The responsibility for the preparation of a paper in a form suitable for publication lies with the author.

- Thesis: IJCBR can publish the summary and abstract of Master and PhD theses in a special issue. 
English: Good quality of written English is required. Spelling may be in British or American English but must be consistent throughout the paper. Care should be exercised in the use of biological terminology that is ill-defined or of local familiarity only. We recommend that authors have their manuscripts checked by an English language native speaker before submission.

Manuscript layout: Manuscripts should be prepared using a standard word processing program and presented in a clear readable format with easily identified sections and headings. The manuscript layout is based on the following directions.

- The main text contains Title, Abstract, Keywords, Introduction, Material and Methods, Results, Discussion, References, Tables, figures.

- The title needs to be concise and informative. Use bold, with an initial capital for the first word only and for words that ordinarily take capitals

- Short (running) title (max 80 characters including spacing).

- The article text should be typed with double-line spacing with wide margins $(2.5 \mathrm{~cm})$.

- The lines must be continuously numbered; the pages must also be numbered.

- Font Calibri 12 should be used for the text, and 12 for the tables, figure legends and references.

- The sections should typically be assembled in the following order:

- Title page contains title, authors' names, full affiliations, acknowledgements and the corresponding author's contacts and Short title.

Abstract (max 250 words, single paragraph): The abstract should be complete and understandable without citation, references, table or figure. Use structured abstract: Background, Aim, Materials \& Methods, Results and Conclusion. The context and the rationale of the study are presented succinctly to support the objectives. The experimental methods and main results are summarized but should not be overburdened by numerical values or probability values. The abstract ends with a short and clear conclusion.

Keywords: Up to five short and specific keywords should complement the title with respect to indicating the subject of the paper in alphabetic order.

Introduction: The introduction briefly outlines the context of the work, presents the current issues that the authors are addressing and the rationale to support the objectives, and clearly defines the objectives.

Material and methods: Material and methods should be described in sufficient details so that others can repeat the experiment. Reference to previously published work may be used to give methodological details, provided that said publications are readily accessible and in English. The code of ethics should be followed for all experiments use animals or human samples.

Statistical analysis of results: The statistical design and the models of statistical analysis must be described, as well as each of the statistical methods used. Sufficient statistical details must be given to allow replication of the statistical analysis. The experimental unit should be defined (e.g. individual or group of animals).

Results: Data are presented as tables and figures. Brief description of the results for each table and figure should be presented. Unpublished data can be mentioned when necessary.

Discussion: Should be separate from the Results section and should focus only on intra- and inter-data discussion (the data in the results section) as well as with the relative data in the literature. Don't repeat information already presented in the Introduction section. Start the first paragraph in the Discussion with a paragraph stating the rationale behind the study, the objectives and the main findings. End Discussion with a short conclusion.

Acknowledgements: In this section, the authors may acknowledge (briefly) their support staff.

Conflict of interest: All papers with a potential conflict of interest must include a description/explanation in a separate heading.

Funding details: The authors should state the source of findings of the study (with research funder and/or grant number). If no fund, the authors should state that the study is self-funded. 


\section{References}

Citation of references: In the text, references should be cited by the author(s) surname(s) and the year of publication (e.g. Salem, 2020). References with two authors should be cited with both surnames (e.g. Salem and Meshrif, 2021). References with three or more authors should be cited with the first author followed by et al. (in italics; e.g. Salem et al., 2021). Names of organizations used as authors (e.g. Food and Drug Administration) should be written out in full in the list of references and on the first mention in the text. Subsequent mentions may be abbreviated (e.g. FDA).

- List of references. Literature cited should be listed in alphabetical order by authors' names. It is the author's responsibility to ensure that all references are correct. All authors should be written and so the full journal name.

- References from journal articles are formatted in APA as this example: Al-Amoudi WM (2018). Toxic effects of Lambda-cyhalothrin on the rat thyroid. Involvement of oxidative stress and ameliorative effect of ginger extract. Toxicology Reports, 5: 728-736.

- References from books or official reports are formatted as this example. Kebreab E, Dijkstra ANM, Bannink A, Gerrits WJJ, \& France J (2006). Nutrient digestion and utilization in farm animals. CABI Publishing. Wallingford, UK.

- References from chapters or parts of books are formatted as this example. Nozière $P, \&$ Hoch $T$ (2006). Modelling fluxes of volatile fatty acids from rumen to portal blood. In: Nutrient digestion and utilization in farm animals (Kebreab E, Dijkstra ANM, Bannink A, Gerrits WJJ \& France J, eds.), pp. 40-47. CABI Publishing. Wallingford, UK.

Tables:

The data should be presented in tables or in graphs, not both.

- Each table should be placed on a separate page at the end of the main text.

- Tables are numbered consecutively using Arabic numbering. They are referred to as Table 1 , Table 2, etc., with capital ' $T$ ', no italics

- Each table has its explanatory caption. The caption is sufficient to permit the table to be understood without reference to the text.

- Abbreviations used in tables/figures have to be defined either as footnotes or in the caption.

Figures

- Package the figures in a single PowerPoint file. Each figure in a separate slide.

- Figure size should be readable in a width of approximately 8-175 $\mathrm{mm}$ (i.e. the maximum size of printing over two columns).

- Ensure that the font size is large enough to be readable at the final print size, use Calibri font to ensure that they are consistent throughout the figures.

- The figures should preferably be provided as TIFF or EPS files.

- The resolutions of figures must be at least $300 \mathrm{dpi}$.

- Preparation of images for a manuscript: For guidance, we refer to the Journal of Cell Biology's instructions to authors (http://jcb.rupress.org/site/misc/ifora.xhtml\#image_aquisition).

- If a cropped image is included in the main text of a paper (e.g. a few lanes of a gel), display the full original image, including the appropriate controls, the molecular size ladder and/or the scale as relevant, as a single figure in a Supplementary Material file to facilitate peer-review and for subsequent online publication.

- Supplementary material is submitted along with the main manuscript in a separate file and identified at uploading as "Supplementary File - for Online Publication Only" The title of the article is included at the top of the supplementary material.

Corresponding author's guidelines: Upon acceptance the corresponding author is required to send his/her recent formal photo to be attached to the front page of the article. 


\title{
International Journal of Cancer \& Biomedical Research
}

(IJCBR) Online ISSN 2682-2628

\author{
Editor-in-Chief \\ Mohamed Labib Salem, PhD \\ Tanta University, Egypt
}

\begin{tabular}{l} 
EACR Board \\
\hline Nehal Elmashad, MD \\
Tanta University, Egypt \\
Nabil Mohy Eldin, PhD \\
Kafrelsheikh University, Egypt \\
Doaa Al-Ghareeb, PhD \\
Alexandria University, Egypt \\
Abdel-Aziz Zidan, PhD \\
Damanhour University, Egypt
\end{tabular}

\begin{tabular}{l} 
Managing Editor \\
\hline Wesam Meshrif, PhD \\
Tanta University, Egypt \\
Sohaila Galal, PhD \\
Tanta University, Egypt \\
Production and Contact \\
\hline Hamdi Kandil \\
Tanta University, Egypt \\
Email: ljcbr100@gmail.com
\end{tabular}

\section{Advisory Board}

Alberto Montero, MD

Taussig Cancer Center, Cleveland,

USA

Yi Zhang, MD

Zhengzhou University, China

Mark Robunstein, Ph D

Medical University of South

Carolina, USA

Mohsen Farid, Ph D

Derby University, USA

Natarajan Muthusamy, Ph D

Ohio State University, USA

Hideki Kasuya, MD

Nagoya University, Japan

Sherif El-Khamisy, Ph D

Sheffield University, UK

Mohamed Ghanem, Ph D

Kafr Elshikh University, Egypt

Sayed Bakry, Ph D

Alazhar University, Egypt

Sameh Ali, Ph D

Nationa Liver Institute, Egypt

Gamal Badr, Ph D

Assuit University, Egypt

Nadia Hamdy, Pharm D

Ain Shams University, Egypt

\section{Editorial Board}

\section{Clinical studies}

Hesham Tawfik, MD

Tanta University, Egypt

Mohamed Attia, MD

Tanta University, Egypt

Mohamed Elshanshory, MD

Tanta University, Egypt

Essam Elshiekh, MD

Tanta Cancer Center, Egypt

Rasha Eraky, MD

Tanta University, Egypt

Shaima Abou-Kjatwa, MD

Tanta University, Egypt

Marcela Diaz, MD

Cleveland Clinic Foundation, USA

Mohamed Abou-El-Enein, MD

Charité Universitätsmedizin Berlin,

Germany
Alaa Eldin Almostafa, MD

McGill University, Canada

Olfat Gadallah, MD

Tanta University, Egypt

Nagla Sarhan, MD

Tanta University, Egypt

Naglaa Fathy, Pharm D

Zagazik University, Egypt

Mohamed Salama, MD

Mansoura University, Egypt

Mona Marie, MD

Alexandria University, Egypt

Preclinical studies

Mostafa El-Sheekh

Tanta University, Egypt

El-Refai Kenawy, Ph D

Tanta University, Egypt

Mohamed Noureldin, Ph D

Banaha University, Egypt

Yousry Albolkiny, Ph D

Tanta University, Egypt

Elsayed Salim, Ph D

Tanta University, Egypt

Shengdian Wang, Ph D

Chinese Academy of Sciences,

China

Sabry El Naggar, Ph D

Tnata Univesity, Egypr

Faris Alenzi, Ph D

Prince Sattam bin Abdulaziz

University, KSA

Ibrahim El-Sayed, Ph D

Menoufia University, Egypt

Tarek Aboul-Fadl, Ph D

Assiut University, Egypt

Rabab Khairat, Ph D

National Research Center,

Giza, Egypt

Wael Lotfy, Ph D

Alexandria University, Egypt

Ashraf Tabll, Ph D

National Research Center, Egypt

Nahla Shoukry, Ph D

Suez University, Egypt
Medhat Eldenary, Ph D

Tanta University, Egypt

Azza Hasan, Ph D

Menufia University, Egypt

Nanees Gamal Eldin, Ph D

Tanta University, Egypt

Mohamed Mansour, UK

Sabbah Hammoury, Ph D

Alexandria Ayadi Almostaqba

Oncology Hospital, Egypt

Nehal Aboulfotoh, Ph D

Zewail City for Science and

Technology, Cairo, Egypt

Amir Elkhami, Ph D

Galaxo, San Francisco, USA

Ahmed Alzohairy, Ph D

Zagazi University, Egypt

Wgady Khalil, Ph D

National Research Center, Egypt

Amr Amin, Ph D

United Arab Emirates

University, UAE

AbdelRahman Zekri, Ph D

National Cancer Institute, Egypt

Hussein Khamis, Ph D

Alexandria University, Egypt

Magdy Mahfouz, Ph D

Kafr Elsheikh University, Egypt

Ehab Elbedewey, Ph D

Tanta University, Egypt

Abeer Badr, Ph D

Cairo University, Egypt

Mamdooh Ghoneum, Ph D

Charles Drew University of

Medicine \& Science, USA

Haiam Abou Elela, Ph D

National Institute of Oceanography and Fisherie, Egypt

Maha EL-Demellawi, Ph D City for Scientific Research \&

Technology Applications, Egypt

Desouky Abd-El-Haleem, Ph D

City for Scientific Research \&

Technology Applications, Egypt 